\title{
Leadership or Management: Expectations for Head of Reference Services in Academic Libraries
}

\author{
Felix E. Unaeze
}

SUMMARY. This paper considers leadership and management issues affecting libraries in general. Specific attention is devoted to academic libraries and their reference departments. It focuses on the dynamics of leadership and management of academic library reference services and what is expected of the reference department head of the 21st century. It explores the changing roles of reference librarians and those of their leaders or department heads. It examines the leadership skills, traits, and competencies and attributes expected of the department head of reference in the new millennium. The paper also examines the paradox of leadership and management and draws distinction between the two terms. It finally looks into whether it is appropriate to have a manager from outside the library profession to be the head of an academic library reference department. [Article copies available for a fee from The Haworth Document Delivery Service: 1-800-HAWORTH. E-mail address: <docdelivery@ haworthpress.com> Website: <http://www.HaworthPress.com> () 2003 by The Haworth Press, Inc. All rights reserved.]

KEYWORDS. Leadership, management, reference department head, reference services, new millennium, 21st century, organization, organizational effectiveness, effective leader, leadership skills, leadership traits

Felix E. Unaeze is Director of Public Services, Douglas Library, Chicago State University, 9501 South King Drive, Chicago, IL 60628 (E-mail: funaeze@csu.edu). He also serves as Library Liaison to the College of Business at the same university.

[Haworth co-indexing entry note]: "Leadership or Management: Expectations for Head of Reference Services in Academic Libraries." Unaeze, Felix E. Co-published simultaneously in The Reference Librarian (The Haworth Information Press, an imprint of The Haworth Press, Inc.) No. 81, 2003, pp. 105-117; and: Managing the Twenty-First Century Reference Department: Challenges and Prospects (ed: Kwasi Sarkodie-Mensah) The Haworth Information Press, an imprint of The Haworth Press, Inc., 2003, pp. 105-117. Single or multiple copies of this article are available for a fee from The Haworth Document Delivery Service [1-800-HAWORTH, 9:00 a.m. - 5:00 p.m. (EST). E-mail address: docdelivery@ haworthpress.com].

http://www.haworthpress.com/store/product.asp?sku=J120

(C) 2003 by The Haworth Press, Inc. All rights reserved. 


\section{INTRODUCTION}

Leadership and management have always been used repeatedly in the human resource industry and often discussed when selecting or hiring the head of any kind of reference department in all kinds of libraries in the United States. The two words have been frequently and interchangeably used in both business organizations and in academic institutions in such a way that they have become the household word when hiring people in all cadres of key positions in those organizations.

Leadership and management are subjects that have attracted considerable interest in the library field. Most researchers working in the area of leadership implicitly assume that leadership is a critical factor in the successful operation of any organization. A few have questioned this assumption and have suggested that other variables might help account for organizational effectiveness. These tend to be environmental influences such as market conditions, the industry, technology, governmental policies, and even factors like internal organizational politics (Gemmill and Oakley, 1992). The dominant principle of organization has shifted, from management in order to control an enterprise to leadership in order to bring out the best in people and to respond quickly to change (Naisbitt and Aburdene, 1990: 218). The library community and indeed our society are saturated with speakers, institutes, articles, books and events about the need for good management and better leadership (Sweeney, 1997: 32). In this era of high technological innovation in most types of libraries, the successful library leader must exercise creative leadership and management of the library's programs, services and resources.

Management and leadership are certainly not new topics but have greatly increased emphasis these days. This paper will attempt to focus on the issue of whether heads of reference departments in academic libraries of today are managers or leaders and at the same time attempt to address the traits, skills, and competencies those heads of reference should possess. In doing this, an effort will be made to define the terms "management" and "leadership," and later find out where the reference department head falls. It will examine the roles of the academic library

department head and see how they can lead the reference department of the 21 st century to its organizational effectiveness.

\section{LITERATURE REVIEW}

Management is the process of working with people and resources to accomplish organizational goals. Good managers do those things both 
effectively and efficiently. To be effective is to achieve organizational goals. To be efficient is to achieve goals with minimum waste of resources, that is, to make the best possible use of money, time, materials, and people. However, some managers fail on both criteria, or focus on one at the expense of another. The best managers maintain a clear focus on both effectiveness and efficiency. The management process when properly executed involves a wide variety of activities, including planning, organizing, leading, and controlling (Bateman and Snell, 1999: 6).

"Leadership is the ability to get work done with and through others while winning their respect, confidence, loyalty, and willing cooperation" (Plunkett, 1996: 359). "Leading is stimulating people to be high performers. It is directing, motivating, and communicating with people, helping guide and inspire them toward achieving team and organizational goals. Leading takes place in teams, departments, and at the top of organizations" (Bateman and Snell, 1999: 7). Intagliata et al. (2000) contend that leadership competencies are considered to be important in the achievement of organizational goals, particularly when the competencies are organization specific, for a number of reasons, including: (1) they guide direction, (2) they are measurable, (3) competencies can be learned, (4) they can distinguish and differentiate the organization, and (5) they can help integrate management practices.

Metz (2001) notes, today, effective library leadership requires an extraordinary ability to maintain a delicate and continually shifting balance in the management of technical, financial, and human resources to serve the academic mission of our colleges and universities.

Leaders must make judicious decisions that blend the strengths of the past, the demands of the present, and the uncertainty of the future, and they must do so continually-often within an organizational environment designed to support the past.

Clearly, "successful library leaders" will need to demonstrate "a blend of bold leadership, informed risk-taking, widespread consultation, and consensus building. They ... will need keen analytical powers, abundant common sense, vibrant creativity, reasoned judgment, and a passionate commitment to the mission and goals of higher education." Metz concluded: "to develop this new leader is an enormous challenge" (p. 2-3).

\section{LEADERSHIP AND MANAGEMENT PARADOX}

McNamara (2002) states, traditionally (although many would now disagree), the term "management" is described as the functions of plan- 
ning, organizing, leading and controlling (or coordinating) activities in an organization. "Managing" is explained as carrying out these activities. Courses in management often teach from this perspective. Some writers follow this view and believe that the activity of leading is but one aspect of management. Other writers disagree and assert that "managing" is planning, organizing, and controlling, and that "leading" is a distinctly separate activity that primarily involves influencing people. An old adage that follows from this latter view is "Leaders do the right things. Managers do things right." Another adage is "Leaders lead people, managers manage things." Other writers would even disagree with this view, however. They would assert that, although a person happens to be carrying out activities that influence others, if he or she does not hold a formal role in the organization with the title of manager then he or she is not a leader (pp. 2-4).

Riggs (1982) argues that management and leadership are two separate hemispheres. Managers tend to work within defined bounds of known quantities, using well-established techniques to accomplish predetermined ends; the manager tends to stress means and neglect ends. The leader's task is to hold, before all persons connected with an institution or organization, some vision of what its mission is and how it can be reached more effectively. Managers may be described as being too busy doing the possible to find time to reach for the difficult or impossible. Leadership involves looking forward, as well as inward (p. viii).

Leadership has its own problems. Bennis (1997) states that there is no simple solution to the leadership problem. But he does give us some insights of leadership of which we should be cognizant:

1. Leaders must develop the vision and strength to call the shots.

2. The leader must be a conceptualist. He or she must possess an entrepreneurial vision and a sense of perspective.

3. The leader must have a sense of continuity and significance.

4. The leader must get at the truth and learn how to filter the unwieldy flow of information into coherent patterns.

5. The leader must be a social architect who studies and shapes what is called the "culture of work."

6. The task of the leader is to lead. And to lead others s/he must first of all know him/herself and utilize his or her strengths to the benefit of the institution (pp. 45-46).

\section{The Differences Between Management and Leadership}

There are some obvious dichotomies when considering the two terms "management and leadership" as shown in the following chart by Kotter (1990). 
The Differences Between Management and Leadership

\begin{tabular}{|c|c|}
\hline Management & Leadership \\
\hline $\begin{array}{l}\text { Planning and Budgeting-establishing } \\
\text { detailed steps and timetables for } \\
\text { achieving needed results, and then } \\
\text { allocating the resources necessary to } \\
\text { make that happen }\end{array}$ & $\begin{array}{l}\text { Establishing Direction-developing a } \\
\text { vision of the future, often the distant } \\
\text { future, and strategies for producing } \\
\text { the changes needed to achieve that } \\
\text { vision }\end{array}$ \\
\hline $\begin{array}{l}\text { Organizing and Staffing-establishing } \\
\text { some structure for accomplishing } \\
\text { plan requirements, staffing that } \\
\text { structure with individuals, delegating } \\
\text { responsibility and authority for } \\
\text { carrying out the plan, providing } \\
\text { policies and procedures to help guide } \\
\text { people, and creating methods or } \\
\text { systems to monitor implementation }\end{array}$ & $\begin{array}{l}\text { Aligning People-communicating the } \\
\text { direction by words and deeds to all } \\
\text { those whose cooperation may be } \\
\text { needed so as to influence the } \\
\text { creation of teams and coalitions that } \\
\text { understand the vision and strategies, } \\
\text { and accept their validity }\end{array}$ \\
\hline $\begin{array}{l}\text { Controlling and Problem Solving- } \\
\text { monitoring results versus plan in } \\
\text { some detail, identifying deviations, } \\
\text { and then planning and organizing to } \\
\text { solve these problems }\end{array}$ & $\begin{array}{l}\text { Motivating and Inspiring-energizing } \\
\text { people to overcome major political, } \\
\text { bureaucratic, and resource barriers } \\
\text { to change by satisfying very basic, } \\
\text { but often unfulfilled, human needs }\end{array}$ \\
\hline $\begin{array}{l}\text { Produces a degree of predictability } \\
\text { and order, and has the potential of } \\
\text { consistently producing key results } \\
\text { expected by various stakeholders (for } \\
\text { example, for customers, always } \\
\text { being on time; for stockholders, being } \\
\text { on budget) }\end{array}$ & $\begin{array}{l}\text { Produces change, often to a dramatic } \\
\text { degree, and has the potential of } \\
\text { producing extremely useful change } \\
\text { (for example, new products that } \\
\text { customers want, new approaches to } \\
\text { labor relations that help make a firm } \\
\text { more competitive) }\end{array}$ \\
\hline
\end{tabular}

Source: A Force for Change: How Leadership Differs from Management by John P. Kotter (p. 6). Copyright $@ 1990$ by John P. Kotter, Inc. Reprinted with the permission of The Free Press, a Division of Simon \& Schuster. All rights reserved.

\section{Management Hierarchy}

Various managers stress different activities or exhibit different management styles and at different management levels. This happens also in libraries and at different levels of management. These individuals do not manage using identical techniques or styles. There are several reasons for these differences, including the managers' training, personalities, orientation and backgrounds. There are different kinds of managers who operate with different styles found at three different management levels in virtually all organizations: top-level, middle-level and lower-level.

Top-level managers are the senior executives of an organization and are responsible for the overall management and organizational effectiveness. In academic institutions, the equivalent of the top-level man- 
agers will be the president, provost or vice president for academic affairs and any other vice president within the institution.

Middle-level managers are found in the middle layers of the organizational hierarchy, reporting to top-level executives. In an academic library setting, the equivalent will be dean or director of libraries.

Front-line managers are lower-level managers that supervise the operational activities of the organization. Also in the academic library setting, the equivalent will be associate or assistant dean of libraries and department heads. Bateman and Snell (1999) explain that the front line managers or operational managers and department heads are directly involved with non-management employees, implementing the specific plans developed with middle managers. This role is critical in the organization, because operational managers are the link between management and non-management personnel (pp. 10-12). Let us take a few minutes to reflect on the leadership traits and skills of an effective leader in an organization.

\section{Leadership Traits and Skills}

The list below demonstrates the leadership traits and skills that are very necessary for an effective leader. This set of traits and skills may be recommended for the reference department head in any kind of library setting:

Traits and Skills Commonly Associated with Leader Effectiveness

List not available for electronic review.

Please see print version. 


\section{ROLES OF THE REFERENCE DEPARTMENT HEAD IN THE NEW MILLENNIUM}

The reference department head plays a very key role in the dayto-day running of the department. This individual should be a transformational leader. The department reference head keeps lines of communication open and provides one-on-one monitoring to develop his or her employees. The department head should have a vision for the department. Riggs (1984) asserts:

In a library setting, the department head plays a central role in the strategic planning process. Along with professional members of the director's office, the department heads constitute the majority of the members of the planning team. A few selected/elected representatives below the department head-level may assist the director with strategic planning. Since strategic planning is essentially a "top-down" process, the department head holds a key position in shaping the future of the library. Many of the goals, objectives, and strategies will most likely be realized through the activities of the departments. Since departments generally have a symbiotic relationship with one another, close cooperation and open communication are required.

Department heads are indispensable in the introduction and implementation of strategic planning. Nevertheless, in many instances, they have to undergo an attitude change about the planning process. They must be able to perceive how change resulting from proper planning can facilitate constructive interrelationships among the various departments. (pp. 15-16)

Reference department heads in academic libraries do all kinds of things from reference desk duties to even keeping library security after Sept. 11, 2001. Sometimes one will be tempted to call reference librarians and their department heads "Jack of all trades and master of none." Some other responsibilities of the reference department head, skills, and traits are summarized below.

\section{Responsibilities}

- Coordinating

- Staff training 
- Research

- Supervision

- Administrative

- Scheduling

- Staff hiring

- Partnership building

- Reference Collection Development

- Information Literacy and Library Instruction

- Information Technology

- Planning

\section{Skills Needed for a Reference Department Head}

- Effective Communication: Oral and Written

- Interpersonal

- Flexible and Adaptable

- Negotiation

- Organizational

- Time Management

Traits That a Reference Department Head Should Have

- Courageous

- Decisive

- Dependable

- Judgment

- Sensibility

- Loyalty

- Enthusiasm

- Endurance

- Initiative

Other qualifications required of a new library leader that will be applicable to a reference department head are listed by Pritchard and Marquardt (2000). They contend that the standard set of qualifications listed in vacancy notices includes skills in management, leadership, planning, budget, communication, collaborative decision making, staff development, fund raising, knowledge of trends in technology and higher education, and, of course, "vision" (p. 2). 


\section{COMPETENCIES REQUIRED OF REFERENCE DEPARTMENT HEADS}

The following recent job advertisements posted in American Libraries (Hot Jobs Online) demonstrate some competencies, skills, qualifications, and roles required of new department heads of reference:

\section{HEAD OF REFERENCE}

XYZ University seeks qualified candidates for the following position: HEAD OF REFERENCE Under the direction of the Director of Research and Information Access Services, the successful candidate will be expected to provide the leadership necessary to develop comprehensive, first class reference services to the university community. Specifically, the successful candidate will supervise the reference desk, including scheduling, monitoring and evaluating service quality, evaluating employee performance and providing reference desk coverage, develop goals and objectives for the reference department, envision and implement innovative projects and services in response to the needs of the university community, identify and evaluate emerging information technologies for implementation, formulate and recommend departmental policies, coordinate documentation of procedures and services, prepare and submit reports to administration as requested, develop initiatives for outreach of reference services to faculty, coordinate Reference Collection Management in collaboration with assigned liaisons, coordinate graduate research liaison, develop and coordinate management of specific in-house resources, teach classes in Information Literacy program as needed in cooperation with Head of Information Literacy, general collection management responsibilities as assigned and in cooperation with the Director of Collection Management. Some weekend and evening hours are required. (American Libraries (Hot Jobs Online))

\section{SHOULD THE HEAD OF REFERENCE BE HIRED FROM OUTSIDE THE PROFESSION?}

The head of reference services for the 21 st century should be an ex-

perienced librarian who will be in a position to win the trust of his or her 
fellow librarians and staff members. This individual should be a librarian who possesses the good leadership skills, traits, and qualities in dealing with the public and all employees. Some libraries have hired people who have some managerial experience, but no library experience, to be head of their reference departments. The danger with that type of practice is that it does not build trust within employees in the department.

Hiring from outside the field will not give proper credence and legitimacy to the profession and it will bring a lot of mixed feelings and bad blood among the reference department staff. Other reasons why it is not advisable to hire department head of reference services from managers who are not librarians are:

- Librarianship is a profession and like other professions, there should be a set of rules and regulations governing and guiding it.

- Minimum educational qualification of an American Library Association (ALA) accredited Master's degree in Library or Information Science is required and must be met.

- Some years of professional experience in the library and information science arena will be needed.

- Good and effective communication skills will be absolutely necessary:

- Knowledge of the library, nuances, lingoes, isms, and jargons associated with the profession and frequently used when interpreting the deluge of resources and technology at the reference desk.

Judging from the above reasons, it will be prudent to consider a librarian with experience, and especially in reference services, the first opportunity to be head of reference before considering a manager who has no library experience or is a non-librarian. A manager without library experience will have a great disadvantage. A librarian who has read the drug literature and has studied drug interaction with the body cannot claim to be a doctor or a pharmacist without adequate training and licenses. The same argument will be appropriate for us to say that an experienced manager, say, from a grocery store, may not be an effective library leader or a good head of academic library reference.

However, with adequate and proper training in reference service, there is still a place for an experienced librarian to head a reference department. This should require some cross-training of that librarian to ac- 
quire some skills and competencies required of a reference department head. Sometimes, this potential and aspiring new reference department head should be filling in at the reference desk for a period of time and learning the patron needs, their patterns of questions and day-to-day operational needs of the reference department.

Another point in favor of hiring experienced librarians from other parts of the library is that their experience counts, and they may also have been reference librarians at some point during their career path. Their training will take less of library financial and personnel resources. So, this idea will be less expensive to the library.

Finally, considering the current declining economic climate and budget woes facing today's academic libraries, it will be cost-effective and reasonable to fill vacant reference department head positions from a pool of experienced librarians already employed at those libraries. This concept will be better than hiring a non-professional librarian manager who has no knowledge of libraries to run an academic library reference department. Hiring a reference department head from outside of the library profession will ultimately demean the profession and cause a perpetual professional rift.

\section{CONCLUSION}

Reference librarianship has experienced tremendous change in the last decade. One of the causes of this rapid change is due to the infusion of technology in the operation of reference services. Technology has seriously affected the way reference librarians and their leaders perform their duties. New methods and approaches have to be introduced for reference librarians to be capable of handling the mixed array of questions coming at the reference desk. It requires reference librarians who have the skills, training and experience to comfort and assist the patrons at the new millennium reference desk.

It takes a good and effective head of reference to lead the troops and to steer the department wheel in the right direction. Every library deserves a good leader. All reference departments deserve good department heads that will be approachable, creative, tenacious, dependable and honest. They must do good service for their departments and follow through on ideas and assignments. The reference department head must possess some time management skills and must be able to prioritize routinely to meet the deluge of demands at the reference desk. The department head of reference services should be both a leader and manager. 
Finally, while commenting on commitment to service, Sherrer (1998) states: "Good service, however, is the result of personal commitment and idealism tempered with reasonableness that combines to produce satisfied users. Paradigms aside, libraries are only as good as their front lines. Their consistency, success, and value are judged at that point. In today's world, that front line may be a person or a computer screen but in either case it must be friendly, approachable, intuitive, and service centered. All of these attributes however must be driven by a commitment to service the public" (p. 16).

\section{REFERENCES}

American Libraries, (Hot Jobs Online). Feb. 4, 2003.

Bateman, Thomas S. and Scott A. Snell. (1999). Management: Building a Competitive Advantage, 4th ed., Boston: Irwin/McGraw-Hill.

Bennis, Warren G. (1977). "Where Have All the Headers Gone?” Technology Review, 79 (March/April): 45-46.

Gemmill, Gary and Judith, Oakley. (1992). "Leadership: An Alienating Social Myth?" Human Relations, 45 (Feb.): 113-29.

Hersberger, Rodney. (1997). "Leadership and Management of Technological Innovation in Academic Libraries." Library Administration \& Management, 11 (1): 26-29.

Intagliata, Jim, Dave Ulrich and Norm Smallwood. (2002). "Levering Leadership Competencies to Produce Leadership Brand: Creating Distinctiveness by Focusing on Strategy and Results." Human Resource Planning. 23. Available online http:// proquest.umi.com/pdqweb.

Kotter, John P. (1990). A Force for Change: How Leadership Differs from Management, N.Y.: The Free Press, 6.

Mech, Terrence F. (1993). "The Managerial Decision Styles of Academic Library Directors," College \& Research Libraries (Sept): 375-386.

Metz, Terry. (2001). "Wanted: Library Leaders for a Discontinuous Future," Library Issues (Jan) 21: no. 3, 2-3.

McNamara, Carter. (2002) "Guidelines to Understand Literature About Leadership" (pp. 1-4): available online from http://www.mapnp.org/library/ldrship/ldng_lit.htm.

Moore, Audrey D. "Reference Librarianship: It Was the Best of Times, It Was ..." The Reference Librarian, 54: 3-10.

Naisbitt, John and Patricia Aburdene. (1990). Megatrends 2000: The New Directions for the 1990's. NY: Morrow, 218.

Plunkett, W. Richard. (1996). Supervision: Diversity and Teams in the Workplace. 8th ed. New Jersey: Prentice-Hall.

Pritchard, Sarah M. and Steven Marquardt, (2000). "Looking for Director Goodboss: How to Recruit a Head Librarian.” Library Issues, 21 (Sept.): 2.

Riggs, Donald E. (ed.) (1982). Library Leadership: Visualizing the Future. Phoenix, Arizona: The Oryx Press. 
Riggs, Donald E. (1984), Strategic Planning for Library Managers, Phoenix, Arizona: The Oryx Press.

Sherrer, Johannah. (1996). "Thriving in Changing Times: Competencies for Today's Reference Librarians" The Reference Librarian, 54: 11-20.

Sweeney, Richard. (1997). "Leadership Skills in the Reengineered Library" Library Administration \& Management, 11 (1): 30-41.

Yukl, Gary A. (1981). Leadership in Organizations, Englewood Cliffs, NJ: Prentice Hall: 70. 